Str Joseph Petavet, F.R.S., Fellow, i873-1936.

Joseph Ernest Petavel was born on August I4th, I873, and educated at University College, London. In 1900 he went to Owen's College, Manchester, as John Harding Research Fellow. In 1908 he was appointed Professor of Engineering and Director of the Whitworth Laboratories of Manchester University, where he worked on the attainment of very high pressures. The following year he was appointed one of the original members of the Advisory Committee for Aeronautics, on which he served after it became the Aeronautical Research Committee, until his death. In I9I I he was appointed a member of the General Board of the National Physical Laboratory and in 1919 he became the director. Knighted in 1920, Sir Joseph Petavel served on many. important committees and councils and was a Past-President of the Engineering Section of the British Association.

Sir Joseph Petavel was essentially an engineer, though most of his work, as an administrator, prevented him from carrying out fully many of his own ideas. Elected to the Society in 1910, his death was a great personal loss to the large circle of friends he had made in aviation.

\title{
John Laurence Hodgson, Associate Fellow, d. August, 1936.
}

John L. Hodgson was an engineer of great ability and originality. He had a very wide range of interests and took an active part in the discussions of the societies to which he belonged. He made the subject of waste particularly his own and showed how, by co-ordinated effort and the proper use of machinery, the working hours of the world could be at least halved. He took a keen interest in all aeronautical questions and was one of the pioneers on testing model airscrews. He was elected an Associate Fellow of the Society in I9I 2.

Robert Alexander Tarleton, Member and Associate Fellow, d. November, $193^{6}$.

R. A. Tarleton was killed in an aeroplane accident near Jodhpur, India, on November 16th, 1936, while on a tour of inspection for the Jodhpur Railway, of which he was the locomotive and carriage superintendent.

Tarleton was a member of the Institution of Aeronautical Engineers before its amalgamation with the Royal Aeronautical Society and also an Associate Fellow of the Society. He served in the Royal Air Force during the war, and though a locomotive engineer, whose duties kept him in India, he continued to keep up his interest in aviation and took every opportunity to fly.

\section{George Geach Parnall, Companion, $d$. June, I936.}

George Parnall was a member of the firm of George Parnall and Sons, shopfitters, which, during the Great War, turned their activities towards building aeroplanes. The interest he then acquired in aircraft was one George Parnall never lost, and when, following the war, his firm sold their business, he decided to enter the aircraft industry. A pioneer of many new and experimental designs, he spared no money to further any project which held out any hope of success. Among the most interesting of the machines produced by George Parnall and Co. was the Parnall Parasol Research monoplane for the purpose of carrying out full-scale research.

\section{Squadron leader Rollo A. de Haga Haig, Associate Fellow, i896-1936.}

Squadron Leader R. A. de. Haga Haig was drowned in a yachting accident near Plymouth on November roth, while trying to adjust the foresail in a storm.

Born at Newcastle-on-Tyne in 1896 , de Haga Haig joined the Royal Flying Corps from the Infantry in 1916 and was quickly recognised as being a pilot of 
far above the average ability. Following the war he became a test pilot at the Royal Aircraft Establishment at Farnborough, and in 1925 carried out the brilliantly successful experiment of flying from the airship R.33 and hooking on to it again. Two years previously he had given, at the R.A.F. Pageant, one of the most brilliant displays of aerobatics and fighting manœuvres ever seen at the pageant.

In 1926 he became the tesst pilot for William Beardmore and Co. and there worked on the monospar system of construction with Mr. H. J. Stieger and afterwards was largely concerned in developing this method of construction.

More recently he was concerned with the radiaura device, which holds out great possibilities for increasing the safety of flying.

De Haga Haig became an Associate Fellow of the Society in 1923. A most brilliant pilot, a mechanical genius, he was one of the best liked personalities in aviation and his early death leaves a gap hard to fill.

\section{Miss Gladys CotTrell, Companion, d. July, 1936.}

Miss Gladys Cottrell joined the Society in 1929 as a Companion, and though not technically trained, showed a very keen interest in aviation and in the training of women engineers.

\section{ADDITIONS TO LIBRARY, 1936.}

\section{GENERAL}

Abridgments of Patent Specifications, Nos. 420,001-440,000.

Aerodrome and Air Route Lighting Equipment.

Aerodynamic Theory, Volume VI, Edited by Dr. W. F. Durand.

Aero Engines ("D" Licence), Third Edition, A. N. Barrett.

Aero Engines, Inspection of, During Mantufacture, Overhaul and Test ("D" Licence), A. N. Barrett. (4th Edition.)

Aeronautical Engineering and Commercial Aviation, A Practical Guide to Your Career. With a Foreword by Capt. G. de Havilland.

Aga Course Indicating Airway Beacon.

(The) Aircraft Year Book for 1936.

Air Estimates, 1935, with Supplement for 1936.

Air Estimates, 1936.

Air Mail, F. V. Monk and H. T. Winter.

Air Mail Operation, Post Office Green Paper No. $23 a$.

Air Navigation Bill, 1935.

Air Navigation Directions (A.N.D. 13), 1936.

(The) Airplane and its Engine (3rd Edition), C. H. Chatfield, C. Fayette Taylor and Shatswell Ober.

Airplane Design (2nd Edition), E. P. Warner.

Airport Management, by Major L. F. Richard.

Air Transport in Great Britain-Some Problems and Needs, Lieut.-Col. F. C. Shelmerdine. (Inaugural Brancker Memorial Lecture, Institute of Transport, 1935.)
Aluminium Tubes and Pipes, British Aluminium Company Limited.

(The) Analysis of Engineering Structures, A. J. S. Pippard and J. F. Baker.

Aviation Training, United States Department of Commerce.

Azimuth Tables, by John Burdwood.

Ballonsport in 1935, Nederlandse Ballonsport-Vereniging.

(The) B.B.C. Annual, 1936.

Bird Flight-200 Action Photographs, Gordon Aymar.

(The) Book of Famous Flyers, J. Mollison.

(The) Book of Speed, 2nd Edition.

(The) Boy's Romance of Aviation, Captain A. O. Pollard, V.C., M.C., D.C.M.

British Polar Year Expedition to Fort Rae, North-West Canada, 1932-1933, J. M. Stagg. (Smithsonian Publication No. 3308.)

Brown's Nautical Almanac, 1936 \& 1937.

Carbon and Alloy Steels, Thos. Firth and John Brown Limited.

(The) Care and Maintenance of a Modern Diesel-Engined Tanker Fleet, H. S. Humphreys.

(The) Carnegie United Kingdom Trust, Twenty-second Annual Report for the Year ending December 31st, 1935.

Andrew Carnegie, The Trusts and their Work.

Civil Aeronautics in the United States (Aeronautics Bulletin No. 1), United States Department of Commerce.

Combustion-Chamber Design for Oil Engines, by Paul Belyavin.

Concrete in Aerodrome Construction, The Cement and Concrete Association. 